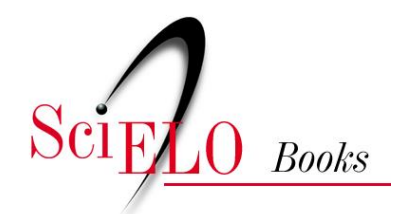

\title{
Seduepb
}

\section{Das percepções sincréticas à síntese}

\author{
Pedro Bergamo
}

BERGAMO, P. Educação universitária: práxis coletiva em busca de veraz qualidade e de precisa cientificidade [online]. Campina Grande: EDUEPB, 2012. Das percepções sincréticas à síntese. pp. 199-252. ISBN 978-85-7879-189-6. Available from SciELO Books < http://books.scielo.org>.

\section{(2)(1)(2)}

All the contents of this work, except where otherwise noted, is licensed under a Creative Commons Attribution-Non Commercial-ShareAlike 3.0 Unported.

Todo o conteúdo deste trabalho, exceto quando houver ressalva, é publicado sob a licença Creative Commons Atribuição Uso Não Comercial - Partilha nos Mesmos Termos 3.0 Não adaptada.

Todo el contenido de esta obra, excepto donde se indique lo contrario, está bajo licencia de la licencia Creative Commons Reconocimento-NoComercial-CompartirIgual 3.0 Unported. 


\section{Das percepções sincréticas à síntese}

\section{A. Autoridade educacional e a questão do valor intangível da liberdade}

Da perspectiva da juventude e na ausência de também cultural despossessão do coletivo natural-mínimo, educação sempre se desvelou como algo de antemão impingível por autoridade que se faz valer já em tal coletivo e na ambiência escolar. Não fosse algo assemelhado com inata generosidade, a provir da própria subjetividade e em resposta a atenções a ela eventualmente devotadas, educar teria de acabar incidindo em uma espécie de "injeção indolor" de imaterialidades (signos e seus significados, ideias, conceitos, valores, hábitos, atitudes e habilidades). É que, por paradoxal que o seja, estudantes têm precisado ser generosos para se capacitarem, não apenas para não mais o serem, mas inclusive para darem conta de como quantificar e aquilatar o quanto lograrão fazer do que seja contrário à sua juvenil generosidade.

Educadores se encontram condicionados por uma pregressa formação. Ainda que esse condicionamento não esteja a contribuir para injetar gananciosidade em seus alunos, não há como negar insuficiência de capacitação pedagógica para evocar generosidade. Já a formação dos alunos tem ocorrido curricularmente determinada no sentido de chegar a um perfil de egresso que manifeste assimilação das mencionadas imaterialidades, ao tempo em que esta assimilação não 
ocorre mediada nem mesmo por discurso sobre gratuidade da perspectiva de quem a gera. Cabe, então, indagar: haveria na ambiência assim formativa uma omissão a se traduzir como "venda e compra" de uma sócio-subjetivada antítese da generosidade? Tratar-se-ia de uma fenomênica particularização do sentido comunicativo do intercâmbio, pela qual esse sentido se torna manifesto à custa de ocultar o alcance também material deste mesmo intercâmbio?

Admissibilidade desses questionamentos e de correspondentes respostas passa pela desocultação da "vontade" humana que tem estado recorrentemente subsumida ao alcance " privacional' do modo de existir" da "escassez criada".

Com efeito, a condição "ausencial" do sentido do modo de ser da "vontade" tem impedido que se avalie o grau de influência da inequivocação quanto a efetivamente produzir na ambiência acadêmica. Já este impedimento tem desandado em prevalência da liberdade como questão de valor intangível. Por sua vez, a prevalência desta questão de valor tem feito com que indiferenciação entre apropriar e produzir se encontre, por tácito ou inconfesso que o ocorra, convenientemente insignificante.

Em contraponto a tal conveniência, a própria insignificância constitui mote para a práxis coletiva de gerar gratuidade se autoafirmar sem risco de se expor a usuais intolerâncias. Ademais, a opcionalidade quanto a ser partícipe de tal autoafirmação acomoda as ideologias que se escudam no intangível valor da liberdade, enquanto, por si mesma, a opcionalidade não frustra, antes até previne, inequivocação quanto a caráter veraz de qualidade educacional. Assim, para convalidar sua "historicidade", a autoafirmação daquela práxis há de presumir que se perscrute a questão da liberdade nos labirin- 
tos ideológicos em que esta mesma questão acabou instalada desde tempos imemoriais.

Alcance intangível da liberdade tem sido realização cultural-civilizatória. Já inequivocação quanto a ser livre presumiria percepção e interpretação da diferença entre apropriar e produzir, ambas - percepção e interpretação - a decorrerem de a "crítico-teoria" se traduzir em práxis coletiva de gerar gratuidade, mesmo que esta tradução tenha que ser conjunturalmente experienciada pelo educando sob a conotação de mero rito de passagem ao longo da frequência à academia.

Já a procedência desta assertiva reside na circunstância de que o exercício da liberdade teria que ocorrer em reciprocidade de coerência com sustentabilidade também coletiva, sob pena de inescapável incidência em injustificações. Por sua vez, tal circunstância não viria a "cair do céu" e a sua eventual existência significaria "alteridade institucional", ou seja, produção inequívoca acabaria opcionalmente empreendida por ser interpretada como imprescindível à liberdade de todos, em vez daquela "historizada" para ser efetiva apenas a poucos, ou mesmo a um só - o senhor, o rei ou o dono do poder.

Assim, a opcionalidade de produzir de modo inequívoco comporia o exercício da liberdade, em vez de o suprimir tal como vem sendo cultural-civilizatoriamente assumido. Trata-se de supressão que tem sido insistentemente criada, à base de sempre mais privilegiada autoinclusão em direitos e autoexclusão das obrigações que são imprescindíveis ou naturalmente institucionais, além de se reportar a ideologias que apregoam universal inclusão em direitos e silenciam sobre discriminada heteroincludência em obrigações não rejeitáveis, mesmo que se perceba e se interprete como injustificada a atribuição (destas mesmas obrigações) apenas aos politicamente menos iguais. 
É em tal perspectiva que nada há de estranho em a mediação político-dominativa, com sua intencionalidade recorrentemente imperceptível nos bastidores do atual e globalista abstracionismo econômico, estar acompanhada por um (místico) encantamento com a prerrogativa científica do método e com os avanços científico-técnicos. É que ambos - método e avanços - vêm perfazendo condições liberatórias da fonte humana de obrigações inequivocamente produtivas, além de incidir em oportunidade de os liberalistas "salvarem positividade de saldos" para a expansão dos seus patrimônios em sentido o mais amplo possível. Para tanto, esta expansão tem de estar cabalmente ideologizada como produção, ainda que, para tanto, os partícipes das ideologias precisem se esconder atrás de biombos organizacionais e ali se transformarem em fontes de recorrentes e multifacetadas condutas apropriativo-particularistas, hoje denominadas capitalísticas. Afinal, não têm existido melhores condições do que aquelas dos labirintos das organizações para, inadvertida e facilitadamente, a pessoa humana se alienar em propriedades que lhe são extrínsecas e ter como se devotar a nada mais do que criar obrigações para estranhos, para despossuídos de tais propriedades e de, a estes, transferir a direta e inequívoca obrigação de obter meios de vida em reciprocidade de coerência com intercâmbio orgânico com a natureza e com o caráter também coletivo da sustentabilidade.

Alterinamente, ainda há de fundamentar-se a única autoridade procedentemente real, ou seja, a educativa, pois a nenhuma outra cumpre arbitrar suspensão da liberdade, por mais que isto ainda precise se delimitar a mero rito de passagem. Já a necessidade ou o problema da passagem por esse rito tem a ver com as recorrentes oportunidades para egressos consentirem em acabar sustentados de forma injustificada e injustificante, à conta da sujeitação de outrem que lhes gere 
sobras de produção, a tanto, cultural-institucionalmente transformadas em direitos. Por seu turno, esta transformação desanda em requisito para silenciar a respeito do sentido de aquelas sobras serem gratuitas. E este silêncio perfaz condição para que essas sobras sejam forçosamente impingidas. Todavia, à base de autoridade educacional, torna-se oportuno, imprescindível inclusive, o apoio do caráter dialético da razão.

Perceber, conhecer e remediar, ou mesmo prevenir, exercício equivocado da liberdade, a desandar em obrigações discriminatórias contra outrem, têm sido desafios cujo enfrentamento talvez precise ocorrer sob efetiva influência de minorias aborígenes, peculiarmente de pele parda e negra, porque ainda não aceitaram as lições de como se obcecarem por ilimitada acumulação de propriedades. É que, à conta dessa obcecação, seria ingênuo admitir que tais desafios sejam encarados até mesmo no discurso politicamente correto, inclusive naquele da razão comunicativa oriunda da teoria crítica e mediadora de uma teoria educacional também igualmente crítica. Por indispensável que esse discurso tenha sido à busca reconstrutiva do conhecimento, cumpre alertar que ainda se encontra tergiversantemente liberalista ao se omitir de imputar significância ao discernimento entre apropriar e produzir, assim como à práxis deste discernimento.

Em sentido inequivocamente alterino e apesar de ainda não se ter sobressaído na história, uma (eventual e assim aborígene) razão há de se refletir e de se realizar em três horizontes do "espaço vital" para o futuro da própria espécie: (a) horizonte em que há de se tornar acentuadamente visível a absurdidade da ilimitável exploração humana, associada à da natureza livre; (b) horizonte em que acabará ridícula a mesmice comportamental de fontes de poder e de (re)-concentração sincrônico-topocêntrica (metropolista) da fixação, 
obtenção e destinação de excedentes gratuitamente obtidos, (re)-concentração atualmente puxada por economicismo precificista e financeirista; e, (c) horizonte de contraposição, a ambos os anteriores, da alteridade atitudinal de assumida fonte de gratuidade, o que, em sentido desalheadamente emancipatório, há de se tornar imprescindível à instauração de sintonia entre as gratuidades de fonte humana e natural-livre.

Apelo à procedência aborígene da "dialeticidade da razão", conquanto de antemão excluso da superioridade cultural, há de reforçar acesso à alteridade de opções curriculares, pois está em pauta a íntegra inteiridade do processo educativo. Ademais, e apesar de o fenômeno pedagógico compreender comunicação interpessoal e estimulação biológico-psíquica, os saberes aprendidos na academia se expõem a estar mediados por opaca intencionalidade político-administrativa e a incidirem em riscos de serem totalizados em alcance tão somente particularizado e específico, ou seja, são ameaçados de redução a estrito teor científico-técnico. Já os riscos, em apreço, têm origem em descolamento, a ocorrer por recurso à comunicação e à estimulação, assim como, e em decorrência deste recurso, a desandar em geração de "lacuna metafísica" por entre forma e conteúdo. Recorrendo-se ao sentido estritamente comunicativo do intercâmbio, tal descolamento tem acontecido por entre significado e significante e em resposta a um outro que tem sido criado à base de estímulos, aquele entre significante e seu real-concreto artificial e só posteriormente (pseudo)-fundamentante. Ambos são descolamentos que não passam de insignificâncias disjuntivas e, por isso, implicam em instituir a (in)-justificação de si mesmos, tendo-se em conta que esta (in)-justificação se faz mediante (re)-apropriação de imaterialidades, estas a se multiplicarem fragmentadas e fragmentárias - como condições existenciais inercial e institucionalmente também criadas. 


\section{B. Uma "pequena narrativa" da (in)-justifica- ção das instituições vigentes}

Alheamento ao alcance também material do intercâmbio, à conta de estímulos ao descolamento entre significante e seu artificial e (pseudo)-fundamentado real-concreto, tem desandado na preterição do caráter íntegro da totalidade do intercâmbio e favorecido que a racionalidade comunicativa se "historize" como particularização da razão humana, apesar das sinalizações em contrário, as quais, recorrentemente, têm incidido em ensaio para a dialeticidade desta mesma razão ser intuída como alteridade de desalheamento.

A excludente superioridade cultural-civilizatória do Ocidente tem respondido a estado particularizado da razão, o que acarreta o paradoxo de que injustificada e injustificante imaterialidade contraste com abundante riqueza material. É que imaterialidade tem sido indissociável de desejo e de interesse no sentido de constituir e até substituir riqueza e, por isso, houve de persistir como primitivismo de incapacidade quanto a prevenir a usurpação do natural esgotamento do parentesco pelo acesso a propriedades extrínsecas à pessoa. Paralelamente, o que importa considerar é a recorrente autoentrega da política educacional, inclusive da educação política que é inerente à competência pedagógica, à reprodução dessa usurpação e daquela superioridade.

Um sintomático registro de tal primitivismo, a se perpetuar na particularização do alcance comunicativo do intercâmbio, já emergiu em versos do memorável estadista ateniense Sólon (apud ARISTÓTELES, 2007, p. 67): "O homem não conhece, porém, nem fim nem medida Que a natureza imponha a arte de enriquecer". 
Obviamente que nada tem sido mais primitivista do que autoentrega às dinâmicas do desejo e do interesse. Por sua vez, essa autoentrega está sendo estimulada por imaterialidades que perfazem, inclusive na atualidade e segundo Saviani (2005, 12), a natureza da educação, por estranho que ressoe uma tal concepção de natureza. Ademais, estimulação coincide com falso atendimento da necessidade ou falsa solução do problema de o parentesco (ou de a "posse do coletivo naturalmínimo”) não se esgotar em termos culturais, o que, levado às últimas implicações, significaria retornar à condição fetal ou ao reencontro com o "paraíso perdido" do cordão umbilical no ventre materno.

Antítese a essa via de permanecer primitivista acabou também registrada, por inconfesso e tácito que o tivesse de ocorrer, nas entrelinhas de texto sobre intercâmbio entre as tribos dos (ditos) bárbaros, texto da lavra daquele mesmo filósofo.

$\mathrm{Na}$ família primitiva, tudo era comum a todos, mas, quando ela se dividiu em partes, os objetos foram também divididos entre estas, ficando alguns privados de algumas coisas; daí a necessidade de trocas. Essa prática é verificada ainda hoje (época de Aristóteles) entre inúmeros povos bárbaros: se uma tribo tem de sobra o que falta a outra, elas trocam o que possuem a mais; por exemplo, trocam vinho por trigo, e assim por diante. Este gênero de transação não está, pois, contra a natureza nem constitui uma espécie separada da ciência da riqueza, visto que, na origem, 
não tinha outro fim senão o da satisfação das necessidades da natureza (Aristóteles, 2007. p. 68. Nossos os termos entre parênteses).

A propósito dos teores dessa citação, resta preterido algo que explique, sobremaneira que justifique, a divisão da família primitiva. Esta família era e ainda é, em resíduos aborígenes, "o" todo, cujo fechamento à totalidade tem ocorrido à base de comum familiaridade com fetiches. Os concretos de pensamento estavam a se restringir à produção que, por sua vez, sempre fora determinada por necessidades naturais e atendimento destas. Trata-se de determinação que não tem sido mediada por discernimento entre o particular (propriedade) e o coletivo (devoluto), dado que a vital-fertilidade humana tem como espontaneamente se dividir entre uma parte "propriamente" autorreprodutiva e outra "impropriamente" heterorreprodutiva. Na insuficiência da espontaneidade desta divisão, adentra-se um dilema: ou o parentesco se mantém estreito pela proliferação de meras tribos, ou então, o trabalho é culturalmente criado em seu alcance enfim sígnico, ao compreender o impingimento da obtenção do "impropriamente" heterorreprodutivo também para estranhos, o que houve de fazer com que a estranheza se tornasse objeto cultural de interesse ou de conveniência e a oposição entre a cultural estranheza e o natural parentesco implicasse transformação social do todo em totalidade - sociedade.

Historicamente, não há como admitir que a desventura das Cidades-Estado gregas, assim como a ventura daquelas que as sucederam até o advento do mercantilismo, sejam explicadas por restrição à “arte de enriquecer”, paralelamente à "historização" das venturas e desventuras a que 
recorrentemente foram expostas as atividades comerciais e bancárias de populações de origem semítica ao longo das suas diásporas, inclusive forçosas e irreversíveis, no Oriente e no Ocidente.

Enquanto separada de conteúdo, forma tem tido sucessivas denominações (notoriamente, a dialética ou ideia superior de Platão, o intelecto agente de Aristóteles e a razão iluminista), o que não impediu a expansão da índole de criar impérios, desde o persa, passando pelos helenistas e romanos, até chegar aos desvarios fascistas e nazistas, entre os anos de 1920 a 1945 do século XX d.C. Durante esse longo período, apropriação particularista da forma em questão só foi ameaçada pela então importância de certo princípio, quando, segundo Russel (1982, p 37), o bispo Ambrósio (340-397 d.C.), em sua popularmente apoiada e heróica não entrega de uma igreja de Milão à ariana imperatriz Justina, deflagrou uma tentativa, conquanto ainda tópica e logo a seguir desvirtuada, de religação entre forma e conteúdo. Ambrósio "demonstrou que havia matérias em que o Estado devia submeter-se à Igreja, estabelecendo, assim, um novo princípio, que mantém até hoje sua importância" (Grifo nosso).

Em tal perspectiva, não resta despropositado recorrer à "dialeticidade da razão" para precipitar alcance íntegro da totalidade do intercâmbio, indo ao encontro de um horizonte que Marx abriu, certamente sem disto se aperceber, à base do que, segundo Manacorda (2007, p. 64), constituiu "flerte" com a dialética no seu pensar por contradições a se fundamentarem na real concretude de contraditórios. Nesse específico recurso, entram em consideração as contradiçõoes que constituem mediação por entre as categorias simples dos valores de uso e de troca. 
Com efeito, intercâmbio tem como ser interpretado a partir do miolo da própria totalidade, miolo que coincide com "incontinuidade-contato" (forma) por entre seu alcance material e seu sentido comunicativo ou imaterial. Para tanto, todavia, o valor de uso ou a utilidade das atividades humanas, e/ou dos resultados destas, precisariam guardar consentida reciprocidade de coerência e de pertinência à sustentabilidade também coletiva, o que implica reciprocidade com trocas orgânicas com a natureza, livre e/ou humana.

Assim, ao se considerar que a própria totalidade do intercâmbio ainda tem sido insuficientemente dinamizada na história, torna-se admissível que as instituições tenham apresentado prerrogativas cuja criação ocorra mediada por imaterialidade recorrentemente separada de materialidade e a separação entre ambas tenha permanecido, interesseira e convenientemente, sempre irreconhecível. Paradoxalmente, a socialização do ônus, correspondente aos sempre mais agigantados desperdícios em que incide tal separação, tem implicado excesso de gratuidade forçosamente impingida à fonte humana e à natureza. Já ultrapassar tal paradoxo não significa retornar à precariedade material anterior ao capitalismo, tal como tem sido pronta e convenientemente alegado; mas, engendrar alteridade de processo cultural-civilizatório, a partir da negação do "nada" (do "não ser" a que tem sido reduzida a gratuidade pelo incontido apropriativismo).

Entretanto, a particularização do sentido comunicativo do intercâmbio já emerge omissa, para não dizer contraproducente, quanto a tal negação, e assim tem permanecido na história da proliferação da espécie humana. Tal omissão se "historiza" em cada um e em todos os indivíduos, sem ultrapassar seu mais radical primitivismo, a coincidir com estágio epistêmico ou autoinsustentável das partes, cujas 
singularidades, por isso mesmo, não se explicam, nem acabam justificadas. Assim, a totalidade humana ainda não se tornou íntegra, porque "incontinuidade-contato", por entre ambos os principais gêneros de componentes do intercâmbio, ainda não é confrontada com o "estar em situação " epistêmica" em relação à perceptibilidade de objetos apropriados e no bojo da escassez criada, nem é assumida como o "ser dialeticidade da razão" por entre o sentido do modo de ser das necessidades e o sentido do modo de ser das funções que as atendem. Esses "não é confrontada" e "nem é assumida" perfazem condição para aventar uma "pequena" narrativa, a respeito da origem e da "historização" das vigentes instituições, indo-se ao encontro do (pós-modernamente admitido) esgotamento da procedência das correspondentes "grandes narrativas", ora sob suspeita de incidirem em meros "fetiches" intelectuais". Ademais, partindo-se desta "fetichização", haveria de permanecer inquestionável que a conquista do poder preceda o privilégio de exercê-lo na gênese da própria dominação.

Quanto a esta precedência, cabe, com apelo a admissíveis verossimilhanças, conjeturar que os primitivos humanos acabaram por se deparar com escassez do que pura e simplesmente apropriar, após proliferarem em espaços onde a vital-fertilidade da natureza lhes era fonte dos melhores e

1 Crise do processo cultural-civilizatório seria aventável como negação da procedência das "grandes narrativas". Em passado longínquo, a emergência do budismo como religiosidade sem deus foi um caso digno de lembrança, diante do alcance mítico do impasse para a ultrapassagem do indiscernimento entre apropriação e produção. $\mathrm{Na}$ atualidade, emergem casos parecidos, a exemplo do "ateísmo cristão" de Luc Ferry (2007) e de André Comte-Sponville (2005), frente à marxiana involuntariedade da inserção nas relações sociais e à consolidação das "injustificações" (desigualdades políticas, das disparidades econômicas e dos desníveis de acesso à tecno-ciência), inclusive entre continentes e ao capricho do individualismo que, por isso ou por complicação da pertinente problemática, não apenas se revigora como ideologia, mas inclusive cria-se áurea de autojustificação. 
mais abundantes meios de vida. Isto sempre significou que suas efetivas referências ou fontes de orientação tenham sido a vital-fertilidade dos corpos das fêmeas, em recorrente e predizível associação com aquela vital-fertilidade da natureza. Ambas essas vitais-fertilidades são espontâneas, materiais e, na pertinente complexidade (ecossistemia, caos e outras propostas de paradigmas), sempre incidiram em heterofagia no nível dos componentes e autofagia enquanto totalidade. Apesar de se dizerem humanos, têm subordinado a tais vitais-fertilidades suas capacidades de pensar, agir e sentir, priorizando, segundo "a lei do menor esforço", aquilo que já esteja pronto, do melhor ao pior. Em decorrência, e desde tempos imemoriais, emergiram desequilíbrios entre necessidades e disponibilidades dos (naturalmente aprontados) meios de vida. Eram desequilíbrios, cujos determinantes, ao início, incidiam em insuficiências do que lhes fosse melhor. Isto houve de induzi-los a disputas. Todavia, as insuficiências tinham como desandar em falta, inclusive do que veio a ser pior, ou mesmo necessário, radical e fatalmente. Então, aquelas disputas tendiam a se tornar fatais e assim tiveram que permanecer, até que, em oásis isolados ou lugares cuja anterior devastação fosse preventiva da presença de novos predadores, alguém se descobrisse capaz de promover a existência de meios de vida, ou mesmo de prevenir até ameaças de que esses meios viessem a faltar. Mas, a condição objetiva da prontidão desses meios continuava a expô-los ao imediatismo de incontidos predadores. Todavia, por serem humanos e mesmo que ainda primitivos, tais predadores acabaram por atinar para a circunstância de que não lhes convinha matar os assim capazes de obter meios de vida. Convinha, sim, arrebatar-lhes uma parte dos resultados que lograssem obter, porém sem prejudicar o necessário para que continuassem exercendo suas capacidades e seu "gosto pela vida", este, tão originário, 
quanto o horror a morrer. Dentro de certos limites, ampliar essa parte arrebatada teria como induzir a que os assim capacitados se tornassem mais produtivos, pois a situação era tal que a única saída possível teria sido aquela de gerarem resultados sempre maiores do que aqueles que lhes tocassem. Então, o próprio predador haveria de se dar conta de que, por força da sua intervenção - estressante, antes de tudo o mais, a ele mesmo e às suas vítimas - teria havido um aumento do exercício das capacidades e dos resultados. Ele próprio passaria a se entender como fonte de referências. E estas, ao serem impingidas, lhe criariam a convicção de serem imprescindíveis, inclusive por ele dispor de meios para evitar que outros predadores ousassem invadir seus domínios, ou mesmo, que constituíssem mera ameaça de tal invasão. Ademais, conviria contar com auxiliares em tais atividades, desde que estes houvessem demonstrado eficiência e jamais viessem a ameaçá-lo, individual ou coletivamente. Tal pactuação entre (um originariamente verossímil) predador-mor e seus cúmplices ter-se-ia "historizado", desde então, em uma institucionalidade (hoje, constituição) pela qual a divisão dos potenciais oponentes garanta que o poder se consolide e se mantenha. Enfim, não seria estranho que, já em seu imemorial primitivismo ou nas suas plurais e recorrentes "historizações", os seres humanos tenham deixado de seguir referências natural-originalmente significativas, apesar de que eles já nasçam com ao menos o potencial de se desenvolverem também em sentido produtivo; especificamente, no sentido de toda pessoa associar sua inata vital-fertilidade àquela que é inerente à natureza.

Eventual sucesso de um tal modelo de sociedade teria possibilitado que a população se expandisse e que aparecessem pessoas em situação díspar no contexto dos próprios vitimados por predação. Ter-se-ia então estabelecido favorabilidade de condições para os mais assim vitimados padecerem 
exploração por parte dos menos vitimados que, por sua vez, teriam tido como se valerem dessas mesmas condições para impingirem a geração de excedentes destinados ao predadormor e a seus prepostos, assim como para quem os explorasse. Enfim, o indubitável produzir teria acabado na hodierna humildade dos extremamente mais vitimados no processo apropriativo, este enquanto organização de todos os predadores, pouco ou nada importando se efetivos (algozes) ou apenas desejosos (vítimas). Mas, limites têm sido inevitáveis, seja à gratuidade, seja à pertinente obtenção. Produtividade nesta obtenção, mediante apoio científico-técnico, torna-se injustificada e injustificante, pela circunstância de esta obtenção só acontecer de antemão e totalmente apropriada, o que implica em incontavelmente mais problemas do que soluções. É que propriedades significam, aos seus detentores, maior probabilidade de acesso a meios de vida, coincidindo com objetos de desejo já realizado. Por sua vez, a incontinência deste desejo faz os objetos apropriáveis se tornarem infinitamente escassos e, como tais, expostos a infindáveis disputas, assim como a recorrentes e sempre mais custosas defesas. Os meios absorvidos no enfrentamento de tais disputas e defesas sempre tiveram como corresponder a meros desperdícios, que são até alargados pela sustentação das instituições voltadas para tal enfrentamento. A insustentabilidade coletiva já é visível em um horizonte em que os conflitos civis passam a substituir as guerras do passado. Disputar e defender propriedades, mesmo que aquelas de estritos direitos, sempre tenderam a usurpar os conteúdos e até o sentido do que propriamente seja educar.

A sustentação dos prepostos do poder sempre jogou papel decisivo na interdependência entre possuidores e despossuídos, o que fez com que esta mesma interdependência se perpetuasse. Mudam esses prepostos, porém não muda a escassez de suportes de poder. Trata-se de escassez que se tornou infinita, 
assumindo o modo "privacional" (vazio, imaterial e não sensorial) como existe a "escassez criada", em radical oposição àquele "presencial" (sensorial, material e plenista) como existem as propriedades que, por mais que sejam expandidas, jamais deixam de ser finitas ou insuficientes. E a dialeticidade que perfaz tal oposição tem como ser abstraída no pensamento e, nesta condição, desdobrar-se em quatro hipóteses: (a) a dinâmica do desejo é real-concreto cuja inerente dialeticidade é apreensível e a própria apreensão incide em inequívoco (auto)-produzir intelectual; (b) dessa apreensão resulta a identidade do modo "privacional" como existe a "escassez criada", identidade que assegura procedência à lógica formal por ter sido, apesar disto ainda ser irreconhecível, a única à qual tem correspondido fundamento real-concretamente inequívoco; (c) quanto ao que acarreta alcance negativo da qualidade em assuntos humanos (dialética do mal), a relação entre perceptível objeto apropriado e "escassez criada" subsiste como via de acesso ao autoconhecimento e ao heteroconhecimento; e, (d) em antítese a esse alcance negativo da qualidade em assuntos humanos, chega-se a alternativas de instituições (fontes de forçosa atribuição de obrigações, a serem inescapavelmente cumpridas por só emergirem no bojo da propriedade) e, por ousado e modesto que o tenha de se "historicizar" (dialética do bem), à "alteridade institucional” (à geração de excedentes de utilidades, fora da propriedade de quem os gera).

A seguir, essas quatro hipóteses se tornam referências de alcance mediativo-dialético. São referências que facultam inferir, às costas ou em ponto cego das alternativas institucionais, o modo "ausencial" como convergem, entre si, os sentidos da exsurgência de necessidades e do exercício de funções para as atender. É inevitável que este sentido e aquela exsurgência guardem, entre si, "incontinuidade-contato" a se desvelar como "razão por entre sentidos" ou como "radicalidade 
dialética de um determinado real-concreto humanizador". Para tanto, o ser humano há de dialetizar-se (conceber-se) por entre apropriar e produzir, ambos e entre si radicalmente desequivocados.

Para deflagrar essa autoconcepção, não seria descabido difundir, entre jovens, a questão de virem a se tornar parcialmente gratuitos em suas atividades e de que é desta conduta que lhes advirão os meios de se sustentarem ou de assumirem adultez. Trata-se de difusão que, diversamente de outras, haverá como futuramente ser explicada e justificada, à base de "dialeticidade da razão" que acabará por deparar-se com a procedente diferença entre apropriar e produzir. À luz dessa razão, também material, será evidenciado que o esforço despendido fora de toda propriedade teria como ser diminuído em uma dominante proporção ou facultaria bem-estar várias vezes maior.

$\mathrm{Na}$ atualidade, o ingresso na educação universitária é o momento mais propício para experienciar "autodialetização" (concepção da própria individualidade, inequívoca e opcionalmente empreendida), ao menos enquanto "rito de passagem".

Todavia, em um mundo do trabalho que se "historiza" no inescapável bojo da propriedade, mediado por competição ou por "criação de escassez", resta óbvio que tal experienciação seja imediatistamente pré-conceituada como disfuncional até a mera sobrevivência.

Nas antípodas de tal disfuncionalidade, certeza sobre a construção do absurdo, em contraponto ao desafio de exercer atividades parcialmente gratuitas, há de gerar tranquilidade e segurança na intimidade da pessoa que passará a entender, em bases real-concretamente fundamentadas, porque têm 
persistido as injustificações das desigualdades políticas, das disparidades econômicas e dos desníveis de acesso à tecnociência. A par disso, torna-se questão, inclusive de sanidade mental, extirpar ilusões, mediante autoconvencimento sobre o que seja algo inequivocamente ético. Todavia, se o próprio processo cultural-civilizatório tem subsistido até o presente, não há de significar "o fim do mundo" conviver com ilusões, ou mesmo admitir que pessoas façam questão de permanecerem iludidas.

Já a contraposição entre construir o absurdo e exercer atividades parcialmente gratuitas facultará ao indivíduo ficar atento às brechas, poros e interstícios, a cujo acesso o "intercâmbio material-comunicativo" tem como ser favorável, para neles instalar um "fractal" de mudança na devida via "críticoteoricamente" emancipatória. Saberá que o ponto certo para instalar esse "fractal" será um espaço ocupacional em que seja ao menos prudente reduzir o absurdo de se ter que pagar sempre mais para produzir. Para tanto, não importa o tipo de ocupação, pois o que está em foco é a fragilidade de quem se ocupa de modo parcialmente gratuito, fragilidade que carece de inusitada mudança institucional para ser protegida.

Em ambiências educacionais, cumpre reconhecer que chegar a tal mudança institucional é desafio que adentra o dilema segundo o qual, ou é despertada a imprescindível competência política no miolo da competência pedagógica ou incompetência pedagógica há de permanecer no bojo da incompetência política. Ademais, não perder de vista a contraposição em causa significará adentrar (o já acima mencionado) "ínferoreferencial" (situação de certezas básicas e inarredáveis, tão duradouras quanto a própria espécie humana), cuja mediação há de coincidir com inusitado congraçamento entre educadores, tendendo a implodir competição na interioridade da 
ambiência educativa, sem prejuízo, antes o contrário, à dinamização das atividades em geral. Profissionais da educação, uma vez assim situados, hão de propender ao reconhecimento de que se deparam com um novel dilema entre serem partícipes do que só teria que dar certo, ou então, assumir, de vez, que toda competição tem dois lados, dos quais o indesejável nem sempre coincidirá apenas com aquele do (tido por) perdedor.

\section{Projeto político-pedagógico}

\section{Projeto enquanto opção inerente à própria concepção}

Projeto é concepção em duplo alcance, por constituir uma formulação, o que é até truístico e, por esta mesma formulação, corresponder a conteúdos que ainda devem se tornar realidade. Assim, o que cabe considerar é a determinação - ato político - dos seus possíveis conteúdos. No caso de estes conteúdos serem pedagógicos, tem-se em conta que tal determinação já emerge circunscrita a um campo de atuação humana e em menor abrangência do que a totalidade deste mesmo campo. Contudo, mesmo que assim circunscrito, o ato político não tem como acabar dispensado de ocorrer enquanto escolhas destes ou daqueles conteúdos da própria pedagogia.

Chega-se, assim, ao que caberia admitir como carência de emancipação da pedagogia, no sentido da necessidade de ela própria não mais deter flancos escancarados à fragmentação que é própria dos objetos de conhecimento, a começar pela multiplicidade de concepções de ser humano e sociedade. 
Por inusitado que o tenha que ser, buscar essa emancipação precisa constituir objetivo primeiro e último de um projeto político-pedagógico. Para tanto, os atos políticos de escolha hão de concretizar-se como atuações que, por sua vez, terão como perfazer pedagogia na situação de "incontinuidade-contato" por entre os dois sentidos do modo de ser "ausencial" de como humanizar, ou seja, por entre o sentido da exurgência de necessidades natural-básicas e o sentido do exercício de funções para as atender em reciprocidade de coerência com intercâmbio orgânico em relação direta ou indireta com a natureza.

No contexto político-educacional vigente, esses sentidos não contam com suas próprias diferenças, pois ainda se "historizam" insuficientemente livres as atuações nas quais ocorrem, vale dizer, escolhas, enquanto relações sociais, não acontecem suficientemente mediadas pelo discernimento entre opção e imposição. $\mathrm{Na}$ ausência de tal mediação, o significado atribuído ao que seja pedagógico torna-se problemático, por necessitar e não dispor de especificidade a toda a prova, especificidade cuja ausência seja consentânea com compreensão dos seus conteúdos na hegemônica condição de estritas práticas didáticas. Trata-se de condição que, por sua própria forma, exclui "incontinuidade-contato" por entre os sentidos de humana e de humanizante dessas suas práticas.

Paralelamente a essa exclusão e ao menos em alcance hipotético, eventuais crises da pedagogia seriam respostas à circunstância de as práticas didáticas não terem como se "historizar" senão à base de conteúdos que vêm sendo ideologizados para que não se evidencie a sua imposição. Saída assim ideológica - que previna tal evidenciação - reside na conduta de sobre-estar narrativas de saberes, cujos fundamentos ou correspondentes reais-concretos somente provenham 
do exterior do educando, peculiarmente se admitidos como reais-concretos humanos. Trata-se de conduta que tem como presumir velada pretensão de que os objetos narrados se tornem universais, mesmo que situados e, com isto, a universalidade da sua imposição tenha como culturalmente se consolidar.

Nesse contexto, encarar a problematicidade das atuações incide em ato político que, por hipotético que precise ainda subsistir, há de acontecer com o caráter ético de "apear da perceptibilidade de objetos apropriados" (deixar de apoiar-se tão somente em objetos externos à pessoa e cuja perceptibilidade os faça serem válidos de forma inconteste) e passar a se perceber na "incontinuidade-contato" por entre, de um lado, o modo plenista, sensorial ou material como existem os objetos apropriados, e de outro, o modo vacual, imaterial ou não sensorial como existe a escassez que é criada à conta de desejos não realizados ou irrealizáveis. Trata-se de perceber "formação" cuja real-concreticidade seja inequivocamente específica, ou seja, que se evidencie mediante radicalidade dialética na oposição entre a identidade a toda prova do modo de existir da "escassez criada" e as diferenças pelas quais dá-se a conhecer o modo de existir dos objetos apropriados. Por isso, cumpre entender que identidade a toda prova ainda há de acabar evidenciada como fundamento primeiro e último da lógica formal, tornando-se imprescindível a toda concepção ou formulação.

Todavia, o perceptível modo de existir dos objetos apropriados, em cuja presença há realização ou repouso de correspondentes desejos ou interesses, não se traduz em suficiente garantia para que esse mesmo repouso seja definitivo. Assim, à conta dessa insuficiência, aqueles objetos não têm deixado de estar sob ilimitável expansão e/ou transformação. Já ameaça de expropriações, basicamente de tudo o que direta 
ou indiretamente venha a garantir o atendimento da necessidade culturalmente criada de estarem de antemão satisfeitas as natural-básicas, faz com que, finalmente, possuidores e/ ou interessados em assim se garantirem percebam aquele alcance vacual, imaterial e não sensorial do modo de existir da "escassez criada", atingindo autoconhecimento e abertura a heteroconhecimento.

Obviamente, o ato político correspondente a "apear da perceptibilidade de objetos apropriados" ainda não ultrapassa gestos de renúncia a propriedades estritamente pessoais, o que ocorre, em rigor, sem razão que os explique e a própria renúncia seja justificada. Tais gestos têm desandado em autoentrega a propriedades comunitariamente administradas, de forma justaposta ou mesmo contraposta às de outrem indivíduos, famílias, ou mesmo, outras comunidades. Max Weber (1982, p. 380-381) argumenta que tais gestos acabam contraditórios, pois a renúncia deixa de fazer sentido à conta de criação de riqueza. Além disso, o próprio Weber (1983, p. 4) assume explicitamente que, em "toda espécie e condições de pessoas", existiu e existe "impulso para o ganho" ou "ânsia de lucro". Todavia, interessado em "fenômenos culturais dotados de um desenvolvimento universal em seu valor e significado" (grifo no original), exclusivos da Civilização Ocidental, esse sociólogo clássico dispensa-se de considerar, ao menos no tópico em questão, a problemática de que aquelas criações de riqueza têm ocorrido, em todo tempo e lugar, alheias à parcial e imprescindivel gratuidade das fontes dos meios de vida. Se injustificações continuavam a ocorrer, inclusive no contexto doméstico do mais ideal-típico Ocidente, no exterior deste, elas estavam em franca dinamização, inclusive em alcance continental (notoriamente, na África, na América Latina e no Sul-Suleste da Ásia). 
Assim, conteúdos pedagógicos em sentido humanizador precisam ser buscados no âmago do que tem sido preterido, quer dizer, no bojo da condição marginalizada, informalizada e sócio-subjetivada, no qual tem acontecido a "relação entre prole e quem, direta ou indiretamente, a sustenta”. A reprodução da espécie responderia a meros instintos feminis ainda incontroláveis, deixando constante margem à interpretação de que todos já nascem "demais", tendo que competir por "um lugar ao sol" (propriedades autoincludentes e heteroexcludentes). Competição não seria fenômeno propriamente cultural, mas premência inata e inalienável, o que explicaria e justificaria as instituições vigentes e pertinente ônus sustentatório. Por terem de ocorrer no bojo da propriedade, existiriam, no máximo, alternativas a essas instituições. "Alteridade institucional" sequer tem entrado em cogitação, pois, nem mesmo esta cogitação teria como ocorrer fora da propriedade, vale dizer, ocorrer como gratuidade vital-fértil que é efetiva na natureza livre e ainda meramente potencial na humana (tida por) adulta.

Dar-se conta da gratuidade, no âmbito da relação entre prole e quem a sustenta, há de incidir no embrião da "historicidade" da razão dialética, daquela ainda a se situar no modo de ser "ausencial" (imperceptível) como convergem os sentidos do mover-se das necessidades e do mover-se das funções de as atender.

Com efeito, faz sentido valorizar, a despeito da ameaça de continuar a prevalecer o contrário nas relações sociais, o inevitável esvair-se das energias corpóreas, desde que tal inevitabilidade seja voluntariamente assumida como oportunidade de a pessoa se dar a própria existência, mediante avisada e prudente conversão daquelas mesmas energias em funções que se voltem para atender necessidades, a começar pelas natural-básicas, pessoais e da espécie. 
Ademais, à base do dar-se conta da gratuidade, evoca-se o que urge ser entendido como "crítico-teoria", ou seja, como evidenciação de que as instituições sempre se "historizaram" seguindo a estratégia de canalizar tal geração da gratuidade para possuidores das respectivas fontes, estratégia que se dá a conhecer pela criação de condições (propriedades externas à pessoa e ilimitadamente garantidas), as quais têm servido para separar, entre si, a exsurgência das necessidades e o exercício das funções para as atender. É essa separação, culturalmente criada, o que explica e injustifica essas propriedades.

À luz dessa "historização" das instituições, resta cristalinamente evidenciável que a gratuidade e sua efetiva fonte adentrem a mais extremada das fragilidades. Por isso, há de restar, também assim frágil, a autoafirmação de conteúdos pedagógicos, tanto humanos quanto humanizantes. Mas, proteger tal escolha incidiria em "alteridade institucional", ainda que em alcance apenas "menos negativo" (com menor ônus sustentatório).

Em decorrência, e na presença daquela autoafirmação pedagógica, um projeto político-pedagógico teria como visar tal proteção, sem que esta, para subsistir, tenha que ser invasora da oportunidade de gerenciar "impulsão para o ganho".

\section{Sentido propositivo-pedagógico de transitar por entre política e ética}

Extemporaneidade usurpadora da relação entre prole ainda naturalmente autoinsustentável e quem a sustenta tem sido culturalmente reproduzida, para não dizer salva, por força da (inercialmente exercida e convenientemente irreconhecível) relação entre dominação política e exterioridade (à pessoa) dos objetos apropriados. Tal reprodução tem ocorrido 
à conta da incontinência apropriativa que sempre desandou em fortalecimento de poucos e enfraquecimento de muitos. Por sua vez, esse fortalecimento tem ocorrido em alcance como que genético-cultural, cuja inercial prevalência na história tem implicado interdependência entre fortes e fracos. É que os fortes têm transferido para os fracos o enfrentamento da inequivocação quanto a efetivamente produzir. Todavia, tal transferência e privilegiada distância desse enfrentamento, além de se equivalerem, têm implicado omissão educacional. Já esta omissão tem correspondido a não compensar redução da natural-finita autoinsustentabilidade juvenil por capacitação adulta a se autossustentar em reciprocidade de coerência com a coletividade e com o intercâmbio orgânico em relação direta ou indireta com a natureza.

A princípio, cabe afirmar que padecimento da sustentação alheia pelos despossuídos de fontes de meios de vida e transferência da sustentação própria pelos possuidores têm sido gestos antieticamente políticos e sempre careceram de uma inversão dialética que os transmute em antipoliticamente éticos, vale dizer, em universal enfrentamento da sustentação própria, assim como da prole ainda disto incapaz e do soerguimento das condições para existir a coletividade em que tal inversão se reproduza incessantemente.

\section{a) Da política à ética}

A exemplo do que já ocorre desde tempos imemoriais, peculiarmente do que acontecia ao longo da Antiguidade Clássica, tem coincidido com dominação política o modo de vida cuja dinâmica presume excedentes de alimentos gerados no exterior das cidades. Em rigor, a geração desses excedentes tinha e ainda tem por contrapartida a prestação de garantias a direitos de propriedade sobre os resultados do 
trabalho alheio. Já estes resultados vêm sendo obtidos à conta de potencial ou efetiva exclusão do acesso à propriedade das fontes de meios de vida - da própria corporeidade (no caso de escravos) e dos recursos naturais. Ao longo da história, gratuidade de capazes de produzir tem sido imprescindível ou institucional. Por ocorrer tão só no interior da propriedade, ela há de destinar-se a outrem que não seja a sua própria fonte, enquanto a pertinente geração também há de ser forçosamente impingida. Neste caso, sua imprescindibilidade está usurpada e seu caráter institucional é alternativo, pois, à medida que ninguém a gera opcionalmente, resta explicada a pertinente imposição, além de apenas ideologicamente justificado o alcance improdutivo do trabalho correspondente àquele de impingi-la.

Todavia, caso fosse possível saber que gratuidade opcionalmente gerada signifique não mais ser explicável sua imposição e acabe por injustificar o alcance improdutivo do trabalho de impingi-la, então os (enfim) sábios se deparariam com "alteridade institucional", no sentido de que a imprescindibilidade de serem gratuitos explique a singularidade pessoal por sua relação com a coletividade e a suficiência desta justifique tal singularidade. Neste caso, os beneficiários teriam que ser crianças e/ou pessoas incapazes de autossustentação, assim como o soerguimento de radicalmente inovadas condições da existência da coletividade.

Na histórica vigência do alcance alternativo da institucionalidade, negar-se a ser parcialmente gratuito tem desandado em ameaça e efetividade de heteroexclusão por parte de possuidores de fontes objetivas de meios de vida, por força da recorrente e implacável ameaça de os despossuídos de tais fontes não terem como acabar beneficiários de resultados do processo produtivo. Este desfecho tem evocado o medo 
da privação, inclusive extrema, insuflando-se o instinto de preservação. Assim, a necessidade de remediar e de prevenir tal privação passa a favorecer estratégias de impor geração de gratuidade aos despossuídos. Trata-se de seguir difusas estratégias político-dominativas, as quais sempre implicaram capacitações para perceber, observar, interpretar e conceituar o potencial e/ou a efetividade de esforço produtivo, porém, tão somente no exterior de si mesmo e no interior das propriedades dos próprios estrategistas. Por sua vez, essas capacitações têm incidido em fenômenos pedagógico-epistemológicos, dos quais derivam insuficiências, ou mesmo ausências, dos presumidos esforços gratuitos, implicando, da parte dos incapacitados, esforços gratuitos maiores do que os justificáveis, ou seja, do que os inequivocamente devidos.

Cabe, então, questionar a recorrência da falta de uma conceituação de injustiça, cujo fundamento real-concreto coincida com a renitente omissão quanto a se comprometer com a devida gratuidade do esforço próprio e com o indevido excesso do esforço alheio. E a resposta há de incidir na inferência de que essa omissão quanto a se comprometer denote falta de autoconhecimento enquanto fonte de dominação política.

A respeito de tal recorrência, resta ao menos admissível que os remotos antecessores do pensar hoje denominado epistemológico (os pais da nova paideia clássico-antiga: filósofos, legisladores e mercadores) passaram a exercer dominação política contra as fontes da mitologia (os pais da velha paideia: sacerdotes, reis antigos e poetas). Entrementes, na história da pessoa singular, tal passagem é recorrente, pois, insuficiência ou mesmo falta total de gratuidade, na esfera desta história, tem desandado em incontrolável "criação de escassez" de espaço vital, a partir de difusos e localizados esgotamentos e/ 
ou "cercamentos" da gratuidade provinda de fontes naturallivres, estas sob acentuada pressão para contrarrestarem com ilimitados aumentos de produtividade. Mediante tal "criação de escassez", a político-dominativa transferência da geração de gratuidade de fonte própria para fonte alheia sempre precisou ocorrer com o apoio de potencial ou efetiva epistemologia, vale dizer, mediada por concretos de pensamento, aos quais correspondem reais-concretos humanamente objetivos - pessoas inequivocamente produtivas, inclusive por insuficiência ou mesmo falta de acesso à própria epistemologia.

Com efeito, significam autodenegações de se tornarem fontes de gratuidade os atos de perceber, observar, interpretar e conceituar reais-concretos apenas transcendentes às pessoas que assim atuam, inclusive os reais-concretos correspondentes a estas mesmas pessoas. Ocorrem tais autodenegações, porque a imprescindibilidade de a pessoa se tornar parcialmente gratuita se encontra liminarmente marginalizada, informalizada e sócio-subjetivada, apesar, ou por conveniência político-dominativa, de se constituir na fundante contraparte de tributos e demais lucros, a decorrerem de (também político-dominativamente criados) direitos de estrita propriedade sobre resultados da produção.

A via de marginalizar, informalizar e sócio-subjetivar a geração de gratuidade, a começar pela pessoal, desanda em obsessão por excedentes que, em decorrência, acabam de antemão justificados, para não dizer que se autoimpõem sob fetichização da produtividade.

A via, em foco, tem estado escondida sob proporção do preço final dos bens e serviços, os quais, para tanto, precisam ser levados a mercado. Neste, o ato político da anuência a contratos de compra e venda, característica de cada uma e de todas as transações, difunde-se e se perpetua, transformando 
conjunturas sincrônico-topocêntricas (ao mesmo tempo e, de preferência, em um único lugar) na estrutura diacrônicotopocêntrica (em épocas sucessivas e, de preferência, em um único lugar) das acumulações de propriedades disparmente acessadas. Porém, é dessas acumulações de propriedade que emana o critério de acesso aos resultados da produção, ou seja, ao sempre mais predominante alcance artificial dos reais-concretos, estes com origem em significantes (pseudo)fundamentais. E é assim que também emana a crescente proporção de tributos e demais direitos de estrita propriedade, proporção que ocorre embutida nos preços monetizados dos meios de trabalho. Já estes meios, que também perfazem aqueles mesmos resultados, desandam em suporte procedimental para a criação do absurdo de se ter que, sempre mais, "pagar para produzir", vale dizer, tornar-se vítima da mais decisiva causa da exclusão social.

Assim, as pessoas que dependem de produzir para acessar resultados, inclusive das próprias atividades, prefeririam também se ocupar com impingir e usar tributos e demais lucros, os quais são criados como direitos a se transformarem em propriedade. Já criação de direitos incide em ato políticodominativo a desandar em "arrogância reivindicalista".

A urgência em obter excedentes sempre mais amplos pressiona por avanços científico-tecnológicos em ciências naturais e em automação, apontando para uma relação direta entre desumanização e depredação da natureza, pelo menos enquanto persistir a político-dominativa insistência em ideologizar desumanização e depredação como se fossem os pertinentes inversos (humanização e produção). Neste caso, ficará ainda mais fenomenicamente oculta a circunstância de que escolha - ato político - de objetos de saber precede ciên- 
cias e estas jamais tenham sido neutras, ainda que reduzidas a estritos instrumentos.

Em perspectiva "crítico-teórica", sempre houve coincidência entre, de um flanco, a incapacidade de a própria pessoa se descobrir e se efetivar fonte de gratuidade e, de outro, o alcance epistemológico da racionalidade em cujas implicações o jugo patronal se torna individualisticamente "menos pior" do que o jugo das necessidades. Já o sentido de "menos pior" adentra valor e, por isso, responde à ética, inclusive enquanto pretexto para perpetuar a moderna vitória da burguesia em bastidores pouco ou nada sondados do individualismo sustentatório, a se refugiar por trás de biombos empresariais e até institucionais.

Quanto ao caráter epistemológico da racionalidade, é imperativo considerar que a condicionalidade da originária "situação epistêmica" tem como acabar reforçada pelo "gosto de viver", ou seja, pelo alcance prazeroso do atendimento das necessidades próprias, a começar por aquelas de contar com a familiaridade do esforço de outrem, isto é, com o que é estrita e endogenamente vivenciado desde a concepção. Trata-se de atendimento que se esgota naturalmente, emergindo contradição como concreto de pensamento a corresponder ao contraditório real-concreto entre escassez potencial ou efetiva e disponibilidade efetiva ou potencial. Escassez há de advir do subjetivo para o objetivo e à conta de desconforto, peculiarmente insegurança subsistencial, enquanto disponibilidade terá de provir do objetivo para o subjetivo e de coincidir com o restabelecimento do conforto, graças a doações, aquisições ou mesmo conquistas. Por sua vez, ao não ter como provir do "gosto de viver", o esforço tem implicado em um recorrente e predizível retardamento cultural - não natural - da percepção do contraditório entre 
escassez e disponibilidade, incidindo-se na propensão pela qual a faculdade de se impulsionar (intencionar-se) e a de racionalizar (relacionar idealmente) se autoentregam a nada mais do que ao atendimento das necessidades próprias, às custas de prévia prontidão dos meios a tanto imprescindíveis e disponibilizados por outrem.

Tal racionalidade tinha que usurpar o espaço da razão em si mesma, ou seja, daquela que confronte, entre si, "criação de escassez" e disponibilidade, além de dialetizá-las genética e genericamente e, com isto, produzir em sentido intelectualinquívoco.

Quanto às implicações epistemológico-racionais de o jugo patronal se tornar "menos pior" do que o jugo das necessidades, elas se desvelam como criação de valores predominantes, segundo três estratos: (a) hedonismo - valoração pela qual o "gosto de viver" desanda em obsessão pelo estritamente prazeroso e, com isso, conserva o contraditório à superfície da realidade, reduzindo-o a falsas dicotomias e destinando o sentido produtivo da dialeticidade para uma "pseudo-transcendência" (princípios ou leis evolutivas; "mão invisível do mercado"; apriorística autonegação da gratuidade humana); (b) fechamento racionalista às relações entre meios e fins - valoração que adentra visões de mundo de conotação excludentemente sistêmica; e (c) material ou subsistencial - obsessão pelo estrito atendimento das necessidades próprias e históricoculturalmente criadas (nunca foram valoradas as necessidades por si mesmas), de forma que acabe inadmissível que seja diretamente assumido o atendimento das necessidades vital-básicas próprias, mas deixado para trás, em uma condição tirante a “aquencendência" (por aquém do próprio "não ser”).

Valores predominantes traduzem éticas que estão descoladas de um produzir dialético, pelo qual o indivíduo se 
descobriria singular e se aperceberia da sua relação com as fontes dos meios de atendimento das próprias e vital-básicas necessidades. E, dada a ausência deste indivíduo, sempre houve como coincidirem ética e política, para não dizer que ambas jamais se tenham diferenciado. É que, sem disponibilizada contrapartida subjetiva em idear, intencionar e aprontar meios de vida, sempre houve que ocorrer inevitável e objetiva escassez da imediata presença desses meios, na perspectiva da melhor para a pior prontidão. Cria-se, em decorrência, antagonismo entre interesses para acessar a melhor prontidão e, à conta de "acessar antes" (chegar primeiro), o real-concreto da incontinência apropriativa. Sucesso de uns em assim apropriar desanda em insucesso de outros para "chegarem primeiro" ao prontamente melhor, depois ao que é "menos melhor", a seguir ao necessário, até que o acesso ao imprescindível adentra o dilema entre disputar - criar o antagônico - ou perecer. É o que caracteriza o fenômeno político: vitória ou derrota, de tal forma que, na derrota, cumpre construir a vitória e, na vitória, cumpre prevenir a derrota - a paz implica a guerra por antecipação. Sucesso, por vezo de origem, é não universalizável e, todavia, solitariamente descabido. Ademais, buscar sucesso tornou-se arriscado e, sobretudo, esfalfante, convindo autoentrega à instintividade de atribuir a outrem o inequívoco ônus de chegar até ele e de concentrar, preferencialmente em si mesmo como único beneficiário, o acesso aos resultados, inclusive como alternativa de hierarquizar interesses. Em desfecho, valoração sincreticamente hedonista, racionalista e materialista é presumida à substituição do jugo das necessidades por outro, desde aquele de conotação hierárquica (caso das castas indianas), passando pelo alcance coercitivo-estatista (caso da cidadania na "pólis" helênica) e chegando ao vezo político-epistemológico-econômico (caso das modernas relações sociais). 
Historicamente, a vitória da burguesia tem evitado sua própria derrota pela racionalidade sistêmica de promover alianças em duas frentes, às quais é comum a valoração ao mesmo tempo materialista e hedonista do "gosto de viver": (a) cumpre extirpar as oportunidades de aprender a produzir no âmbito familiar, microempresarial e comunitário, estimulando-se a preferência pela renda nominal-monetarizada em dicotomia com acentuado descrédito da renda real-concreta; e, (b) criam-se oportunidades de os prepostos do poder regulamentar-político endividarem o Estado para atender demandas sociais em franca inchação, o que pressiona o aumento da carga tributária e da margem de rendas privadas líquidas; estrategicamente, da margem que incide sobre serviços de dívidas públicas, precipitando-se, não só o imperativo de pagar sempre mais para se ter acesso a ocupações formalmente remuneradas, como também a competição precipitadora de interesses individualistas em busca de imprescindível saída (auto)-sustentatória.

É na trama daquela preservação da vitória da burguesia que urge entender a transformação da escola em departamento a dar conta da especialidade de promover valoração do "gosto de viver", a par da capacitação para a cidadania confundida com "arrogância reivindicalista", ambas - valoração e capacitação - socialmente funcionais ao incremento de tributos e/ ou do endividamento do Estado. Para tanto, há de acabar de antemão preterido o contraditório entre o permanecer no que é familiar (no "gosto de viver") e adentrar estranheza (participar de um processo de produção cuja dinâmica implica renúncia à inconfessa melhor parte dos imprescindíveis resultados). É em tal contraditório que se configura a tendência à metropolização do modo político ou antiético de conviver. Cria-se uma realidade em que a imprescindível sustentação pessoal se torna acentuadamente privilégio, à medida que 
direitos se tornam propriedade a se reconcentrar, graças à garantia conferida à propriedade exterior à pessoa, ou seja, ao "norte" sistêmico.

Entretanto, universalizar (democratizar) acesso à propriedade não tem como incidir em questão de direito, pois feriria, custosa ou proibitivamente, interesses vitoriosos e, como tais, transformados na propriedade de direitos. Com efeito, remediar conflitos apropriativos tem implicado a própria e onerosa existência das instituições e, por isso, inexiste algo de mais custoso do que a contestação da propriedade, sobremaneira aquela de direitos. Ademais, a recorrente remediação de conflitos contestatórios da propriedade de direitos tem incidido, prévia e calculadamente, no impingimento à produção de acentuada produtividade e isto, ao presumir ilimitação de excedentes, não passa de saída cuja enigmática teleologia permanece inacessível aos (próprios e elitistas) beneficiários.

Em desfecho, apropriação privilegiada se torna tão imprescindível quanto a produção mesma, o que implica estimular retornos privados líquidos como requisito, também imprescindível, para que tributos sejam gerados.

$\mathrm{Na}$ modernidade ora vivenciada, a história pessoal continua totalmente à mercê do epistemologismo, cujo reflexo tem estado no político-dominativo apelo a avanços em ciência e tecnologia, na (ainda irreconhecível e ilusória) pressuposição de que, para vitoriosos inclusive, não sobrevenha o "inferno" (abundância da escassez criada, a coincidir com gratuidade negada, apesar de o real-concreto da própria gratuidade se constituir na imprescindível contrapartida dos componentes da mais-valia - tributos e rendas privadas líquidas). Em desfecho, política tende a desandar em antiética "arrogância 
reivindicalista", peculiarmente ao se tentar democratização do pertinente exercício.

\section{b) Da ética à política}

A emergência do contraditório conflituoso presume a escassez que, por sua vez, é criada pela incapacidade de a pessoa descobrir-se e se efetivar fonte de imprescindível gratuidade. O efetivo alcance humano da situação dessa pessoa é aquele de incapacidade de obrigações (antieticidade) ou de inescapável cessão parcial da capacidade própria de direitos (heterocondicionamento político).

Já a "criação de escassez" coincide com efetiva e/ou desejada autonegação da gratuidade de fonte própria nas relações sociais de produção, negação cuja efetividade procede de precoce anuência a valores na esfera da subjetividade e é inercializada como fenômeno sociocorporativo. Inferência de tal efetividade presume recurso à dialética que perfaz a dinâmica do desejo, uma vez que o caráter coletivamente imprescindível da geração de gratuidade tem sido cultural-institucionalmente atribuído aos mais fracos e estes jamais deixaram de almejar a situação oposta. Por isso, e se os atores em jogo forem adultos capazes, a dicotomia fraco-forte há de compreender contato, ou mesmo intercessão, dos contrários. Em tal jogo, ninguém é suficientemente forte que previna toda ameaça de assalto às propriedades extrínsecas a própria pessoa. Da mesma forma, nunca se é tão fraco que não seja possível exercer funções em algum proveito próprio.

Na perspectiva de que é inevitável enfrentar o jugo da necessidade e na anuência à "sujeitação" (preferência pela relação patrão-empregado), a experiência da involuntária produção inequívoca não faculta intuir a "situação diastêmica" (situação mediativo-dialética) da pessoa por entre as 
abstrações correspondentes à prole e a quem 'sustenta. Nesta "diastemia", ao contrário do que ocorre naquela "sujeitação", a espécie será perpetuada à conta de relações entre espécimes que, por sua vez, hão de explicar-se como fonte da gratuidade que é absolutamente imprescindível à prole e serão justificados pela suficiência das condições de perpetuação da espécie da qual procedem. Explicação e justificação da pessoa singular hão de ocorrer em bases "sincrônico-topomúltiplas" (ao mesmo tempo e em muitos lugares) e "diacrônico-topoúnicas" (em tempos sucessivos e em um mesmo lugar, vale dizer, em bases que precisam caracterizar o modo urbano de convivência). Escassez terá como ser prevenida; porém em acordo com limitações que são naturais ao sentido inequívoco e opcionalmente empreendido do produzir.

Um ainda irreconhecível determinante das limitações do poder e da fraqueza tem emergido na trama das relações sociais implicadas no modo urbano de vida, tendo-se em vista que a ambiência citadina presume "intercâmbio material-comunicativo" em cuja dinâmica sempre surgiram oportunidades de ultrapassagem do "panóptico" controle da produção campesina que não prescinde de um durável e exposto acesso à condição objetiva da terra em que tem seu lugar.

A propósito do esgotamento de tal controle, já as antigas cidades helênicas encontraram precedentes de suas constituições em suas similares no imemorial "berço" (terras adjacentes e águas do Mediterrâneo Oriental) do "intercâmbio materialcomunicativo".

Controlar de modo "panóptico" as relações sociourbanas incidiria em "insustentabilidade coletiva" (em custo proibitivo, por presumir exacerbação de conflitos apropriativos nos contrafortes sociais da obtenção dos meios a tanto imprescindíveis). A avolumação dessas relações veio a ser a principal 
característica da urbanização, que se acentuou com a modernidade. Na história atual, até as atividades rurais já assumiram conotação urbana, na perspectiva de que se tornou impraticável a autossuficiência do pertinente empreendimento.

Em decorrência, a insustentabilidade material do controle social como real-concreto da prática política tende a incidir em insustentabilidade institucional, cujo reflexo é incidência em abertura de espaços democráticos como precedentes da oportunidade para autogoverno - este, a requerer um humanismo de perfil mais universalista no nível da singularidade pessoal.

Todavia, a busca de um tal humanismo resulta inconciliável com o reducionismo tecnicista que está a absorver todo o potencial de aprendizagem da pessoa para que esta se garanta sua mera subsistência, inclusive enquanto partícipe da elite a se esfalfar para manter e ampliar propriedades com as quais chega a até mesmo se confundir. Insuficiência de percepção dessa inconciliabilidade traduz-se na disputa entre maximização do Estado e minimização do Mercado ou inchação deste e minguamento daquele, disputa que houve de ocorrer de forma alheia à emergência de oportunidades emancipatórias a serem assumidas como "ínferos referenciais" de "alteridade institucional", de incondicionamento político, ou ainda, de referenciação ética.

Eticidade se torna historicamente oportuna na acentuação da insustentabilidade institucional. A rigor, ela procede do questionamento das instituições, à medida que estas são apropriadas pelos seus prepostos, o que houve de acabar subsumido nas injustificações que decorrem da forma de obtenção dos meios sustentatórios de tal apropriação, tendo por inescapável desfecho a valoração da sincrônico-topocentria do metropo- 
lismo, a decorrer da involuntária inserção dos sustentadores nas relações sociais, a partir daquelas de produção.

Eticidade e involuntariedade são radicalmente antitéticas. Todavia, eticidade há de emergir consentânea com "alteridade institucional", bem ainda com subjetividade e com emancipação. Assim, para que ética entre em pauta como "assunto socrático", torna-se imprescindível que se questione uma institucionalidade que sempre se impôs de modo topocêntrico, bem como a cumplicidade entre o exclusivismo da objetividade da Ciência, em apontar o que "teria de" fazer história, e o legalismo da Norma, em coibir o que "deveria não" fazer história.

Institucionalidade e eticidade carecem de inequivocação quanto ao que seja "o" imprescindível, pois este facultaria a ambas uma referência comum. Sabe-se, antes de tudo o mais, que "o" imprescindível é a espécie se reproduzir, mediante produção de meios de vida "por aquém" dos requisitos sustentatório-metropolísticos - estes, estritamente individualistas e/ou corporativistas. De fato, este "por aquém" coincide com atitudes (como que) "aquencendentes" à racionalidade precificista e/ou financeirista, esta a se caracterizar por funcionalidade sociológica à obtenção de tributos e demais rendas de estrita propriedade e por disfuncionalidade humana a dar conta da autoinsustentabilidade da prole. Por sua vez, esta prole tem de subsistir mediante excedente de produção a se originar em outrem que, ao prescindir de parte do que lhe pertence por inequívoco mérito, assume gratuidade de parte do seu próprio esforço produtivo ou dos resultados deste. $\mathrm{Na}$ ausência de tal "irracionalidade", a procriação teria de conformar-se a interesses e incidir em contrassenso emancipatório e em sócio-subjetivação sustentatória da prole. Já esta conformação, ao avançar do metropolismo, passa a ser 
fonte de inusitados contraditórios, a começar por aquele de “impositividade de emancipação". Paralelamente, autoinsustentabilidade se transmuta em violência, à conta, não apenas da postergação cultural do seu natural esgotamento à chegada da adultez humana, como também da perda das suas referências moral-culturais.

Em suma, incide-se em situação existencial-pessoal que tende a se traduzir como "estar demais", por implicar competir por um (tácito) absurdo que é inerente à circunstância de a emancipação ser compulsória em vez de opcional ou de a dependência ser livre em vez de involuntária. Trata-se de circunstância que desanda em falta de autenticidade no "intercâmbio material-comunicativo" ("afetividade" apenas nas aparências e a refletir agressividade latente, ou então, agressividade nas aparências a refletir "afetividade" latente). Esse "estar demais" é patogênico, ao transformar o "escapismo" mítico de antanho em "internalizacionismo" alheante (a pessoa tem que existir como "sendo" o que, não importa como, the seja inicialmente inculcado e finalmente por ela mesma buscado, apropriado, conquistado, sequestrado, consumido, conhecido enfim ${ }^{2}$ ), assim como em "apetite" para construir o absurdo, mediante obsessão por estrita prática. Aproxima-se, caso não já estiver efetiva, uma crise de referenciação cuja ultrapassagem requer que a imprescindibilidade

2 A conotação histórico-cultural da pedagogia apontaria para tal "artificialização" da pessoa, à medida que certo psicologismo estaria a intentar engendrar a consciência do ser social. A propósito, cabe reproduzir um excerto de texto de L.S. Vigotsky (FORMOSINHO, KISCHIMOTO E PINAZZA, 2007 apud PIMENTEL, p. 225): “Qualquer função psicológica superior foi externa (e) social antes de ser interna... Todas as funções no desenvolvimento cultural da criança aparecem duas vezes ou em dois planos... Aparecem primeiro entre pessoas como uma categoria intermental (interpsicológica), e depois no interior da criança como uma categoria intramental (intrapsicológica). Isso é igualmente verdadeiro para a atenção voluntária, para a memória lógica e para a formação de conceitos" (grifo nosso). 
de inequivocação quanto a produzir se torne comum ao que é institucional e ao que é ético, incidindo em mediação dialogal-dialética entre ambos.

A rigor, está a emergir uma crise da falta de discernimento entre o restar absurdo do "estar demais" e o fazer sentido do "gosto pela vida". A persistência dessa crise se traduz em uma encruzilhada entre, em uma direção, incondicionalidade política enquanto eticidade não mediada por inequivocação quanto a produzir e, em outra direção, condicionamento político enquanto eticidade mediada por essa mesma inequivocação, questão que se candidata a incidir em "assunto socrático".

Nesta última direção, entraria em questionamento o dilema entre ser ou não ser absurdo "estar demais", a menos que persista uma pertinente autoentrega ao "gosto pela vida", assim como uma conexa inciência. É que emerge, ainda na adolescência, a natural necessidade de emancipação autossustentatória, necessidade que, após a Revolução Industrial, se defronta com sempre mais abrangente impasse resolutivo quanto ao pertinente atendimento, evocando o dilema entre "ser" ou "não ser" absurdo "estar demais". E, na ausência de resposta à altura do pertinente problema, uma eventual e radicalmente "crítico-teórica" percepção do absurdo quanto a "estar demais" tem como desandar em precoce desespero. Caberia, então, questionar: até que ponto seria possível prevenir a percepção do "estar demais"? Qual a influência do "internalizacionismo" dos fatos culturais? Não se estaria a evocar o "estar demais" para precipitar violência juvenil? Seria de antemão descartável a hipótese de que a violência seja ao menos correlata ao "internalizacionismo" que caracteriza a pedagogia colonizada por psicologismo histórico-cultural? 
A propósito de tais questões, seria utópico retornar aos tempos em que a autossustentação se diluía naquela domiciliar e/ou comunitária. Em contraponto, o novel e metropolístico isolamento pessoal, peculiarmente em alcance também autossustentatório, induz à percepção do atendimento da estranha necessidade de não se ter as demais, a partir das básicas e daquelas da própria espécie na imediata condição do espécime. E isto constitui a esteira cujo movimento faz adentrar ao contraditório de se incidir em vítima ou em algoz da "sujeitação" própria ou alheia, respectivamente.

Nas histórias pessoal e social, torna-se oportuno questionar a falta de sentido de nascer e subsistir tendo necessidades, a começar pelas básicas e da espécie. $\mathrm{Na}$ ausência de tal sentido, atendê-las mediante produção também não faria sentido. Mas, se produção, própria ou alheia, tem de existir, ela há de assumir um significado que lhe é inalienável. Ademais, a automação total (ainda) resta utópica, porque, antes de tudo o mais, teria que ocorrer fora da propriedade de excludentes direitos sobre os pertinentes resultados e dos meios de estes serem obtidos. Assim, acesso a tal sentido terá que, ao contrário do que sempre se verificou, incidir em mais do que "nada", para se ir ao encontro do natural esgotamento da autoinsustentabilidade, em contraponto ao "internalizacionismo" que tem sido alheio às naturais e singulares potencialidades pessoais.

Por hipotético que ainda o tenha que persistir, impõe-se questionar a involuntariedade da inserção nas relações sociais, a começar por aquelas de produção. E tal questionamento há de inaugurar eticidade referenciada no sentido de produzir de modo inequívoco e opcionalmente empreendido. 


\section{3. "Alteridade institucional": proteção à fragilidade da autoafirmação propositivo- pedagógica}

A conjunção entre sentido humanizador das atuações pedagógicas e opcionalidade em as assumir há de significar alteridade àquela entre involuntária inserção nas relações sociais de produção e sociabilidade historicamente hegemônica. A propósito de ambas essas conjunções, tenha-se em vista o teor de uma assertiva em franca aceitação na IES em causa: "inequivocação quanto a produzir é o único assunto que há de ser considerado em todo tempo e lugar, porque, se a produção inequívoca não for opcionalmente empreendida, a sua imprescindibilidade se torna "ocasião que faz o ladrão" (constitui-se na oportunidade de a dominação ideologizar sua própria justificativa). Por que tal assunto tem pré-estado banido da prática educativa por inexplicável omissão das práticas políticas, tanto de educadores, quanto de prepostos institucionais?

Ainda que precise não ultrapassar mera hipótese, há uma lição contida nessa assertiva: determinada educação política tem como incidir em mudança qualitativa das relações inerentes à instituição em que ela própria se processa, ao passo que política educacional depende de inequivocação quanto a humanizar os prepostos e partícipes do processo político, dependência que responde à referida omissão, esta a se reproduzir na própria ambiência educativa e naquelas em que atuam os egressos vitimados por essa mesma omissão.

Em decorrência, cabe questionar a fundamentalidade do significado do que seja institucional em sua relação com o fenômeno político. Desse questionamento, infere-se que tal significado não tem como se desvencilhar de ranço ideológico, 
urgindo que seja esvaziado de quaisquer pretensões de inconteste justificativa.

Para início de arrazoamento dialético, não há como continuarem entre si desvinculados o que é naturalmente imprescindível e o que está culturalmente instituído como tal. Trata-se de desvinculação em que se encontra enredado o processo educativo, sem que os seus prepostos e partícipes se apercebam de que esse mesmo enredamento tem a ver com interessença em uma proposta pedagógica que se torne hegemônica, à medida que competência pedagógico-técnica passe a perfazer o emergente primado da competência tão só científico-tecnológica. Trata-se de competência em cujos domínios chegar-se-á à total anulação de conteúdo propriamente humano, anulação a ocorrer em duas e visceralmente cúmplices perspectivas: (a) por superfluidade, excrescência ou sobra, de tudo o que, alterinamente, houvesse de provir do interior para o exterior da pessoa; e, (b) por conteúdo tão somente adquirível ou a proceder de fora para dentro da pessoa que passa a se confundir com suas propriedades.

Por mediato que o precise ser abordado, a primeira dessas perspectivas tem sido resposta inerente à circunstância de a científico-tecnologia só emergir no bojo da propriedade, o que implica contestação do critério de o acesso aos resultados da produção guardar proporcionalidade direta com a extensão das propriedades. Para tanto, têm sido criados, em bases político-institucionais, direitos sobre tais resultados a serem transformados nessas propriedades, estando, à testa do processo, tributos e rendas privadas (líquidas de tributos), com suas inevitavelmente privilegiadas destinações.

Trata-se de contestação cuja processualidade desanda em guerra sem fronteiras, tirante à concepção heraclitiana do princípio filosófico-explicativo do mundo. "A" saída tende 
a incidir na determinação das injustificações em bases científico-tecnologicistas, bases que, a partir da história atual, venham a ultrapassar a logicidade natural-imperativa, tirante àquela registrada por Aristóteles a respeito da vocação dos bárbaros para serem escravos. Por sua vez, essa logicidade já ultrapassara, como se presume, a imemorial origem mítica das castas entre povos sul-asianos. Ademais, tal saída é de antemão incompatível com a prevalência dos valores da democracia e da cidadania. Assim, ou estes valores acabam preteridos, ou a pertinente "salvação" incidirá em "arrogância reivindicalista" e decorrente acirramento de conflitos, realimentando-se, não apenas os custos de sustentação do Estado, como também o preço da "sedução" dos empreendedores para gerarem meios que cubram estes mesmos custos. Em síntese, a absurdidade em construção tende a se tornar visível, até mesmo àqueles que não a admitem senão pela via fatal - por revolução às avessas de acabarem, real-concretamente, por ela atropelados.

Retornando às duas enunciadas perspectivas, a segunda, de acordo com a qual o conteúdo humano se reduz ao que é estritamente adquirível, tem a ver com alienação inercialmente autoconstruída. A pessoa é máscara ou estrita expressão de fenômenos reduzidos a um único, ela própria, a coincidir com uma acumulação de propriedades, cujos suportes advêm tão somente de fora para dentro. E este "dentro" é estrito resultado de fenômenos que têm de se transmutar em um suporte "aquencendente" (assimétrico a transcendente). A pessoa mesma não se admite enquanto originalidades inextinguíveis, mas existencialidade estritamente multideterminada e a se historizar em sincrônico-topocentria. Ela é não valoradora, ou mesmo antivaloradora, de limites natural-materiais. Estende-se por além da própria corporeidade e, para tanto, cerca espaços vitais que ela confunde com a sua própria existência e que passam a revesti-la. Ela, todavia, 
assume o "modo de existir "privacional"” (vazio, imaterial ou não sensorial, em que há de subsistir não mais do que desejo de si mesma e em cujo vácuo só cabem propriedades). Não fossem estas propriedades, a pessoa estaria totalmente esvaída, indeterminável e indefinível. Assim, à conta desta condição, as propriedades têm de subsistir atropeladas umas pelas outras, carentes de espaço para ocuparem e, ao mesmo tempo e lugar, extinguindo-o a todo custo ou preço.

É óbvio que ambas aquelas alternativas (de acabar anulado o conteúdo propriamente humano) devam ser rejeitadas, ao se considerar o significado de competência propriamente pedagógica. No bojo desse significado e apesar da inciência a seu respeito, persiste ao menos potencialidade de conteúdo inato, inalienável e imprescindível, ou seja, potencial de gratuidade. Em prol de tal rejeição, cabe discernir, em âmbito dominativo, o alcance animalesco da heterofagia apropriativa a acabar seletivamente aculturado como se produção o fosse e, no âmbito emancipatório, a radicalidade dialética do que restou deixado para trás, na irreconhecível esfera da mera generalidade, a (não menos animal) gratuidade de um excesso de intercâmbio orgânico com a natureza. E este excesso sempre se constituiu no que é mais radicalmente imprescindível à espécie (propriamente) humana, ou seja, à sua própria (re)produção ou à sustentabilidade também coletiva.

À base de tal discernimento, ainda a coincidir com um primeiro ato alterinamente cultural, é que a razão dialética viria a coincidir consigo mesma e a aperceber-se intelectualprodutiva. Tal ato assumiria procedência radicalmente diversa daquela do objeto filosófico da ideia hegeliana, a coincidir, conforme Habermas (1982, 28-43), com o (auto)-exame das condições de ela por si mesma se historiar. Por sua vez, este historiar-se já emerge no bojo da apropriação. Por isso, na 
imanência da propriedade, acabam por dissolver-se, um no outro, o modo de existir "privacional" da escassez criada e o modo de ser "ausencial" da "vontade". Sutilezas? Sim, não fosse também assim emergirem o alcance materialista da dialética em Marx e o caráter comunicativo da razão em Habermas, implicando que o proceder dialético, em ambas as circunstâncias, incida em alternativas e não em alteridade ou em inequivocação quanto a produzir intelectualmente.

Ao expor como o proceder dialético na comunicação racional em Habermas sucede ao materialista em Marx, Heck (1982) sumariza:

[... A pedra de toque da dialética materialista é o trabalho e não a conversão do homem. [...] cumpre dialetizar tal concepção de saber (dialética enquanto trabalho) com dados sócio-antropológicos como interação, comunicação, linguagem, poder. Para uma teoria do conhecimento, não pode ser indiferente, segundo Habermas, se o trabalho é encarado como um proceder instrumentalista ou se, como grandeza comunicativa, ele medeia também as leis que em Marx o regulam. Tal a priori dialético do materialismo, isto é, a incapacidade de negar seu princípio naturalista faz, de acordo com Habermas, que a teoria da sociedade se encontre apenas embrionária em Marx, que o fim da gestação desta teoria implique o corte do cordão umbilical que liga Marx às forças produtivas do século passado (XIX). (p. 15. Grifos no original. Nossos os termos entre parênteses). 
A respeito de dialetizar concepções de conhecimento, não há como prescindir de cada uma e de todas elas serem divididas. Na dialética materialista, trabalho não tem como emergir de antemão dividido, pois o próprio dividir-se já incidiria em trabalho, a não ser que se crie "lacuna metafísica" entre ideia de dividir trabalho e ideia da ação deste dividir. Assim, subsiste tão somente uma alternativa para a dialética materialista se libertar de metafísica, aquela de admitir, de uma vez por todas, que divisão do trabalho tem de significar autoafirmação e autonegação do próprio trabalho, prevenindo-se que ideologização de tal contraditório signifique também trabalho. A par disso, não se incide em nenhum deslize intelectual ao se reconhecer que tal ideologização tem coincidido com indiscernimento entre apropriar e produzir. Negar-se a trabalhar implica apropriar, uma vez que humano algum é anjo, ou seja, estar pura e simplesmente vivo significa já estar de antemão remunerado em termos de sustentabilidade. Esfalfar-se com impingir dominação nunca foi, é ou será inequívoco trabalho, ainda que na acepção de improdutivo. Entretanto, não é precisamente a tal impingir que Habermas se reporta, mesmo que admita dialetizar poder. Por isso, este aparece na citação acima como dado sócio-antropológico e em uma sequência tirante àquela de uma sucessão de notícias midiaticamente comunicadas.

Inferência cabível, ainda que hipotética, daquela exposição de Heck reside na preterição do alcance material do intercâmbio, às costas ou em ponto cego da concepção de trabalho em Marx e de sentido comunicativo da razão em Habermas.

Marx - custa não o admitir - subestimou, em seu método da economia política, a relevância histórica da categoria simples cujo real-concreto tem sido o intercâmbio de utilidades, ainda 
que o tenha abordado com especificidade diversa daquelas preferidas pelos economistas clássicos. O objeto propriamente científico da economia incide nas trocas de utilidades, em vez de nas circunstâncias em que as próprias trocas acabam incontidamente apropriadas (ranço politicista da economia, tão abundante nas análises de Marx). Na ausência de trocas, delimitações da produção se tornam impeditivas de propiciar amenização do padecimento do jugo da necessidade.

Quanto a Habermas, também custa não admitir que esteja a postergar o alcance material do intercâmbio, para não dizer o próprio intercâmbio enquanto matriz de fissuras, brechas e poros à emancipação no monólito da propriedade. Tal postergação ainda há de acabar atribuída à "situação epistêmica" da qual se projeta o olhar do observador. A propósito de tal situação, Freitag e Rouanet (1980), ao apontarem a perspectiva epistemológica na obra de Habermas, especificamente no livro intitulado "Conhecimento e Interesse", deixam transparecer que o real-concreto correspondente ao alcance material do intercâmbio sai de cena em favor de outro cujo concreto de pensamento incide em conhecimento instrumental (em oposição a comunicativo):

O conhecimento instrumental permite ao homem satisfazer as suas necessidades ajudando-o a libertar-se da natureza exterior (por meio da produção); o conhecimento comunicativo o impele a emancipar-se de todas as formas de repressão social (ou de seus representantes intrapsíquicos). Ambos estão, portanto, a serviço da emancipação. Esta é ao mesmo tempo um fim em si e um marco dentro do qual 
a teoria crítica consegue perceber as demais ciências, e a si própria, como interessadas (FREITAG e ROUANET, 1980. p.13. Grifo no original).

À luz dos teores dessa citação, cumpre indagar se o interesse emancipatório da própria teoria crítica emergiria isento de dominação, ou se, contrariamente, o próprio interesse não desandaria em "lacuna metafísica" (vazios espontaneamente subentendidos por entre categorias do pensar).

Em princípio, uma resposta seria alcançável, recorrendo-se ao proceder especificamente dialético, à base do qual, a teoria crítica (conhecimento) seja divisível entre os gêneros instrumental e comunicativo. Já estes gêneros também são divisíveis em espécies: o instrumental é definível como material e libertador do homem contra a natureza, enquanto o comunicativo é definível como imaterial e emancipador contra a repressão social. Chega-se, então, à inevitabilidade de se inferir vazios por entre as formas de imaterial e de emancipador, vale dizer, não se sabe como termina o imaterial e se inicia o emancipador ou vice-versa. Ignora-se, também, como a forma do comunicativo se superpõe às formas das suas espécies, sem que ocorra fim-começo ou começo-fim por entre forma superposta (dominativa) e formas subpostas (dominadas). Igualmente, a forma instrumental se superpõe a ambas as formas das suas duas espécies e por entre estas espécies há distância nada mais do que subentendida. Ademais, tem que existir fim-começo ou começo-fim por entre as formas genéricas de instrumental e de comunicativo. Tal inferência de vazios tem permanecido insignificante, nula ou um zero à esquerda. Entretanto, é nesta mesma insignificância que estão inevitavelmente a se apoiar os pés do observador. Assim, a sustentação do observador, na ausência 
de intercâmbio, teria que estar de antemão assegurada pela sociedade: a (ainda juvenil) autoinsustentabilidade do observador estaria a depender de ele ser proprietário da teoria crítica, assim como de criar escassez de tal propriedade. Todavia, "intercâmbio material-comunicativo" tem permitido a Habermas trocar suas publicações, assim como suas atividades de pesquisador e de professor, por utilidades que lhe têm possibilitado sustentar-se e contribuir para a sustentação coletiva, mediante pagamento de impostos e outras contribuições.

$\mathrm{Na}$ ausência das trocas, especificamente das sobras levadas a intercâmbio, a produção nunca ultrapassaria seu estágio (ainda e até mesmo) pré-bárbaro. Por isso, não resta de antemão descabido admitir aquela subestimação em Marx e essa postergação em Habermas. Ambas talvez procedam de eventual carência de análises comparadas entre mudanças sociais ao longo da emergência das cidades-Estado clássico-antigas e da urbanização moderna.

Em desfecho, uma eventual matriz de fissuras, brechas e poros emancipatórios, a perfazer o real-concreto do "intercâmbio material-comunicativo", continua deixada para trás, postergada ou preterida, de forma tão inciente a ponto de que "produzir educação" equivaleria a apelar para espantalhos, inclusive entre educadores meramente "noticiados" a respeito da dialética histórico-materialista.

Todavia, esses mesmos educadores não se cansam de reivindicar uso de tributos para sustentar suas atividades, de forma alheia à radical incompatibilidade entre tributação e humanização crítica. Paralelamente, eles não avançam em competência educativo-política para procedentemente argumentarem no sentido de a destinação de tributos ao processo 
educativo assumir reciprocidade de coerência com sustentabilidade também coletiva ou com parcial gratuidade de quem gera esses mesmos tributos, persistindo no imaturo e deseducativo discurso da gratuidade na perspectiva de quem apenas a recebe, nega ou apropria.

\section{Síntese dialeticamente arrazoada}

Livres empreendedores e prepostos do Estado precisam se dar conta de que, no pós-marxismo, eles deixam de ser, respectivamente, diretos e indiretos exploradores do trabalho humano, para serem vistos, junto à "arrogância reivindicalista", como detentores de riqueza ilimitada. Pouco ou nada importa tentarem explicar e, sobremaneira, justificar condição diversa. Por que, então e pragmaticamente, não acumular retornos de capital e arrecadar tributos, a todo custo ou preço? Prepostos do Mercado e do Estado estariam a se expor a surpresas dialeticamente arrazoadas? Qual o vínculo entre educação e a eventualidade de tais surpresas?

Ao que desde já é admissível ao menos conjeturar, nada impediria que mudança social provenha do ainda embrionário significado educacional da situação de "ínfero- referencial" (por entre o sentido de se ser parcialmente gratuito nas atividades docentes e o absurdo de se ter que sempre mais "pagar para produzir" serviços educativos). Antes de tudo, essa situação há de significar surpresa que emerge arrazoada, em bases dialéticas ou intelectual-inequivocamente produtivas.

Com efeito, alcance universitário da educação presume abertura, ao menos esta, à mediação que coincide com "incontinuidade-contato", esta enquanto parte por entre partes (ética e arte-estética) da totalidade (a própria educação) e, por força de tal mediação, o que significa universitário há 
de perfazer diferença própria e de forma onipresente às diferenças das demais partes (ética e arte-estética). Assim é que autoconhecimento, enquanto fulcro (razão) de um processo humanizador a se desdobrar também em ética e arte-estética, tem como ser deflagratório da busca de sentido propriamente universitário da educação. E, se esse fulcro não se autoafirmar por entre as diferenças das partes e a partir do "miolo" da totalidade (ética, razão e arte-estética), esse mesmo sentido não se coloca, nem mesmo em hipótese.

Deflagra-se o processo humanizador, a partir da percepção pelos mestres e pelos discípulos do caráter básico e inarredável da situação do "ínfero-referencial" (momento da "dialeticidiade da razão" que se depara situada por entre "absurdidade em construção" e geração de "gratuidade" coerentemente com "sustentabilidade também coletiva"). Este lugar-momento há de ser propriamente histórico e de coincidir com dialeticidade em si mesma. Nesta coincidência se "disformam" (opõem-se) razão e ciência. Em um (enfim) visível horizonte, ciência tem implicado desumanização a perfazer o binômio política-técnica (autoentrega à capacitação para construir absurdidade). Em outro (também enfim) visível horizonte, razão ainda há de facultar humanização em que ética e arte-estética detenham as próprias diferenças e, concomitantemente, estejam em mútuo contato. Em tal condição, ciência e técnica hão de interagir mediadas pela totalidade humana configurada por ética, razão e arte-estética, graças à opção pessoal por capacitar-se a mudar, no sentido de se ser coerente com "sustentabilidade também coletiva".

Tal coerência refletirá autoconhecimento e este coincidirá com porta de acesso a heteroconhecimento, à medida que valoração e rejeição de reais-concretos passem a afetar a relação ensino-aprendizagem e isto tenha como favorecer 
percepção e interpretação. Ademais, desalheamento quanto à mediação intelectual-produtiva há de perfazer condição de discernimento e de este facultar que os termos discernidos entrem real-concretamente em contato. Contrariamente, imotivação a conhecer tem respondido à estranheza dos reaisconcretos cuja mensurabilidade se torna excludente critério de perfazer o cosmo.

Há possibilidade de dinamização do acesso a heteroconhecimento, não apenas enquanto "afetividade" inerente à relação entre ensino e aprendizagem, como também enquanto congraçamento entre as próprias pessoas na ambiência universitária.

Quanto a prevenir estranheza, cumpre ter em vista que o natural esgotar-se da autoinsustentabilidade individual urge ser compensada por contrapartida cultural que, ademais, carece de coerência com sustentabilidade também coletiva. Mas essa compensação tem sido postergada, inclusive indefinidamente, à conta de omissão educacional. Já remover tal omissão há de incidir em razão mediativa por entre imaturidade e desequivocada adultez. Por seu turno, o significado mediativo da razão reside em prevenir "salto por sobre limites" da imaturidade e da própria adultez. A oportunidade de essa prevenção ser deflagrada coincide com a idade em que os jovens passam a se preocupar com autonomia, com profissionalização e/ou ingresso na universidade. Deflagrada, neste nível educacional, tal prevenção há de extravasar, à montante e à jusante, a atual graduação universitária.

A propósito desse nível, um sutil alerta é encontradiço nas entrelinhas do texto de Pistrak (2000, p. 169-223) sobre a auto-organização dos alunos e enquanto, também, fundamento da escola do trabalho. Essa auto-organização acabou - seria impossível negá-lo - por se "historizar" como 
estimuladora do interesse (em vez de evocadora da generosidade) na juventude comunista. Por sua vez, esse estímulo poderia ter aberto flancos a interpretações, até antitéticas ao que seja trabalho, a respeito da denominação de "trabalho improdutivo" que, segundo esse mesmo autor, "não é feliz" (p. 84). Trata-se de infelicidade que se confirmou com a futura derrocada do socialismo. Esta já era previsível aos próprios educadores soviéticos, logo após a Revolução de 1917, na postura política, formada ainda na juventude, que acabou silenciosamente cúmplice dos desmandos de Stalin, apesar dos milhões e milhões de egressos da "escola soviética do trabalho" cuja denominação talvez fosse mais verídica caso se denominasse "escola soviética da apropriação do poder". "Mutatis mutandis", o mesmo acontece na atualidade dos escritos de Mészáros (2005, p. 74-5), nos quais emergem imbricadas educação continuada e "prática significativa de autogestão", pressupondo que, a ambas, preceda universalização do ensino e do "trabalho como ativididade humana autorrealizadora" (p. 65). É que o significado desta última expressão emerge dialógico-alheado à inequivocação quanto a produzir, algo que o apelo à categoria "trabalho" efetivamente nunca supriu. Autogestão ainda carece de evocar mudança institucional no sentido de reduzir a própria negatividade, protegendo a condição radicalmente frágil de toda fonte de gratuidade. 